\title{
Kecemasan Anak Korban Bullying: Efektifitas Terapi Menulis Ekspresif Menurunkan Kecemasan
}

\author{
Salmiyati $^{1}$, Wiwik Sulistyaningsih ${ }^{2}$, Eka Ervika $^{3}$ \\ ${ }^{1}$ Fakultas Psikologi, Universitas Islam Negeri Sultan Syarif Kasim Riau \\ Jl. Hr. Soebrantas no, 153 Km 13, Pekanbaru, Riau \\ ${ }^{2,3}$ Fakultas Psikologi, Universitas Sumatera Utara \\ Jl. Dr. Mansyur no 52, Medan, Sumatera Utara \\ salmiyati@uin-suska.ac.id
}

\begin{abstract}
Abstrak
Salah salah satu dampak psikologis bullying bagi anak, adalah munculnya kecemasan. Intensitas kecemasan akan terlihat dari reaksi fisik, emosi, kognitif serta perilaku anak. Pada penelitian ini, terapi menulis ekspresif digunakan sebagai intervensi untuk menurunkan kecemasan anak korban bullying. Kecemasan diukur menggunakan modifikasi skala Spence Children's Anxiety Scale (SCAS) meliputi area kecemasan, separation anxiety, general anxiety, social anxiety, panic/agoraphobia, obsessive compulsive dan fear of physical injury. Responden penelitian, 2 orang laki-laki dan 6 orang perempuan dengan rentang usia 9-12 tahun. Ada 2 kelompok (ekperimen dan kontrol) dengan setiap kelompok terdiri dari 4 orang anak. Uji Mann Whitney, memperlihatkan bahwa tidak terdapat perbedaan kecemasan antara kelompok eksperimen dengan kelompok kontrol $(\mathrm{r}=0.72 ; \mathrm{p}>0.05)$. Selanjutnya pada kelompok eksperimen dilakukan uji wilcoxon, didapat hasil bahwa terapi menulis ekspresif tidak efektif menurunkan kecemasan anak korban bullying $(\mathrm{r}=-0.13 ; \mathrm{p}>0.05)$. Beberapa faktor yang menyebabkan kondisi tersebut terjadi diantaranya, responden belum memperoleh insight dari terapi yang dilaksanakan, tidak terpenuhinya karakteristik terapi menulis ekspresif, bullying masih terjadi, rentang pelaksanaan menulis dan individual karakteristik. Akan tetapi, temuan lain yang diperoleh dari penelitian ini adalah terapi menulis ekspresif mampu menjadi media katarsis bagi responden.
\end{abstract}

Kata kunci: Terapi menulis efektif ; kecemasan ; korban bullying

\begin{abstract}
One of the psychological effects of bullying for children is the emergence of anxiety. We will see the intensity of anxiety from the physical, emotional, cognitive and behavioral reactions of children. In this study, we used expressive writing therapy as an intervention to reduce the anxiety of child victims of bullying. We measured anxiety using a Spence Children's Anxiety Scale (SCAS) comprising six areas of anxiety, separation anxiety, general anxiety, social anxiety, panic / agoraphobia, obsessive-compulsive and fear of physical injury. The research respondents comprised 2 men and 6 women with an age range of 9-12 years. Then divided into 2 groups (experiment and control) with each group comprising 4 children. The Mann-Whitney test shows the results that there is no difference in anxiety between the experimental group and the control group $(r=0.72 ; p>0.05)$. In the experimental group Wilcoxon test was performed, it was found that expressive writing therapy was not effective in reducing anxiety of children of bullying victims $(\mathrm{r}=-0.13 ; \mathrm{p}>0.05)$. Some factors that cause this condition occur include, respondents have not gained insight from the therapy carried out, not fulfilling the characteristics of expressive writing therapy, bullying is still happening, the range of implementation of writing and individual characteristics. However, other findings got from this study are expressive writing therapy that can be a cathartic medium for respondents.
\end{abstract}

Keywords: expressive writing therapy, anxiety, bullying victim 


\section{PENDAHULUAN}

Bentuk Perilaku agresif di sekolah diantaranya adalah Bullying. Bullying dapat terjadi antara sesama siswa, guru dan siswa, sesama guru ataupun pihak-pihak lain yang berada di lingkungan sekolah. Jumlah kasus bullying yang tercatat oleh Komisi Perlindungan Anak (KPAI) sebanyak 25\% dari keseluhan pengaduan bidang pendidikan atau sekitar 369 kasus dari tahun 2011 hingga 2014 (Firmansyah, 2014). Kondisi ini memperlihatkan bahwa terjadi peningkatan kasus bullying di Sekolah.

Bullying dapat terjadi dalam bentuk fisik, verbal ataupun relasi. Bullying seperti memukul, mendorng menendang, menampar. Bullying verbal seperti mengejek, ancaman dan intimidasi. Bullying relasi seperti menyebarkan rumor atau kebohongan tentang seseorang dan mengucilkan. Ong (2003) mengatakan bahwa bullying tidak disebabkan oleh faktor tunggal, melainkan beberapa faktor diantaranya dinamika keluarga yaitu cara setiap anggota keluarga saling berinteraksi, media, aturan dalam kelompok yang menyebabkan munculnya gagasan mengenai bullying bukan sebagai masalah besar, teknologi yang memungkin bullying terjadi melalui dunia maya serta budaya sekolah

Suatu peristiwa kekerasan dikatakan sebagai kasus bullying, jika memiliki karakteristik bullying. Bullying dapat terjadi disebabkan oleh pelaku memiliki kekuatan lebih dibandingkan korban, pelaku sengaja melakukannya untuk menyakiti korban dan dilakuan berulang (Gillette \& Danniels, 2009). Bullying yang sering terjadi disekolah-sekolah, pada umumnya sudah dilakukan oleh anak yang ditakuti oleh anak lainnya, sehingga ia bebas untuk berbuat kekerasan terhadap targetnya tanpa menunggu anak lain berbuat kesalahan kepadanya, dan terjadi lebih dari tiga kali dalam satu bulan. Oleh karenanya, peristiwa bullying menjadi peristiwa yang terus berulang dan dapat dilakukan oleh siapa saja.

Korban bullying biasanya memiliki karakteristik berbeda dari anak lainnya, baik secara internal maupun eksternal. Karakteristik eksternal anak-anak korba bullying diantaranya ukuran fisik yang berbeda (lebih kecil, besar atau tinggi), berbeda secara etnik, agama, budaya atau berbeda dari aspek kemampuan. Sedangkan karakteristik internal yang dimiliki dinataranya pasif ketika dibully, bersikap provokatif atau sulit berinteraksi dalam lingkungan sosialnya (Murphy \& Banas, 2009). Beberapa kasus yang terjadi, seperti di salah satu sekolah menengah pertama di Jakarta, memperlihatkan anak yang dibully tidak mampu atau diam saja saat dibully. Semakin banyak karakterikstik korban bullying dimiliki oleh seorang anak atau siswa, maka semakin besar pula kemungkinan untuk menjadi target bullying.

Dampak dari bullying dapat dirasakan oleh kedua pihak baik korban maupun pelaku. Bagi pelaku bullying, mengalami luka fisik akibat dari perilaku delinquent dan bahkan di keluarkan dari sekolah (Gilliet \& Danniels, 2009). Bagi anak yang menjadi korban bullying, dampak psikologis yang muncul dan dirasakan diantaranya merasa takut, cemas, marah, frustrasi, tidak berdaya, merasa sendiri serta dijauhi orang lain (Ong, 2003) dan bila terjadi pada anak-anak akan menjadi lebih terinternalisasi (Swear, Espelage \& Napolatino, 2009).

Froggatt menyebutkan kecemasan merupakan perasaan tidak nyaman dan takut dengan disertai gejala fisik, seperti denyut jantung semakin cepat, mulut kering, tubuh berkeringat serta gemetar (Supriyantini, 2010). Kecemasan juga dapat menjelaskan periode dan pola umum dari perasaan serta gangguan klinis signifikan (Hauggard, 2008). Gejala yang diperlihatkan dari kecemasan, diantaranya gejala fisik (otot tegang, pernapasan menjadi cepat, jumlah keringat yang kelur bertambah, mulut menjadi kering), Emosi (perasaan takut, gelisah dan mudah marah) dan kognitif (sulit konsentrasi, khawatir, dan memikirkan sesuatu yang tidak realistik), Perilaku (respon bermusuhan meningkat, agresi, menghindar).

Kecemasan pada umumnya merupakan emosi yang normal, namun dianggap sebagai 
gangguan jika berlebihan mengganggung kehidupan sehari-hari. Ketika kecemasan mulai mengganggu aktivitas kehidupannya, maka anak akan memperlihatkan perilaku yang berbeda. Diantaranya anak akan menolak untuk ke sekolah dengan mencari-cari alasan, menjadi lebih pendiam, dan merasa takut untuk bertemu dengan lingkungan yang terkait dengan penyebab kecemasan tersebut, kekhawatiran berlebih mengenai kejadian yang sudah ataupun akan terjadi, khawatir terhadap penampilan, munculnya perasaan tegang, mengeluh sakit tanpa penyebab fisik yang jelas, tertekan dalam situasi sosial, phobia dan obsesisif kompulsif (Dadds \& Barret, 2001).

Menulis ekspresif merupakan salah satu metode yang dapat membantu mengurangi kecemasan. Melalui menulis, individu tidak perlu ragu atau khawatir disalahkan dalam mengungkap dan mengeksplor pikiran dan perasaan mereka (Bolton, 1999; Bolton, 2011). Selain itu individu secara berlahan menjadi mampu untuk lebih baik memahami dirinya sendiri dan membantu mengatasi depresi, distres atau kecemasan yang dialami (Bolton, 2011). Menulis ekspresi merupakan bagian dari terapi kreatif yang menggunakan pendekatan seni, musik, tari, menulis bermain dan konseling rehabilitasi (health care). Terapi menulis ekspresi memberi kebebasan kepada individu dalam menggunakan kata dan bahasa dalam berbagai bentuk, seperti puisi, menulis cerita karangan bebas atau lirik lagu (Malchiodi, 2007). Dengan demikian, melalui metode menulis ekspresif individu mendapatkan media untuk mengekplor dan mengungkapkan pikiran ataupun perasaan terkait dengan hal-hal tidak menyenangkan dalam hidupnya, yang selama ini sulit diungkapkan.

Proses terapi menulis ekspresi sebagai tindakan intervensi, dilakukan melaui 4 tahap (Malchiodi, 2007). Tahap pertama disebut dengan tahap recognition, dimana pada tahap ini individu akan dibantu membuka imajinasi, memusatkan perhatian, relaksasi serta menghilangkan ketakutan. Individu diajak untuk menuliskan sesuatu yang muncul dalam pikirannya tanpa adanya perencanaan. Tahap kedua adalah tahap examination yaitu tahap terapi. Individu akan mengeksplor reaksi pikiran serta perasaan melalui tulisan tentang suatu peristiwa tertentu. Sesi pertemuan berkisar antara 3-5 sesi, dilakukan secara berurutan dengan durasi menulis 15-30 menit (Pannebaker \& Chung, 2007). Tahap ketika disebut juxtaposition yaitu tahap refleksi, untuk memperoleh keadaan baru, perilaku, sikap, nilai serta pemahaman diri yang lebih baik. Individu diperbolehkan untuk mengeksplor kembali tulisannya dan mendiskusikan dengan orang lain atau kelompok. Tahap keempat yaitu tahap aplication to the self yang merupakan tahap terakhir proses terapi. Individu dimotivasi agar mengaplikasikan yang telah diperoleh dan dipelajari selama proses terapi ke kehidupannya sehari-hari (Malchiodi, 2007).

Berdasarkan uraian di atas terapi menulis dianggap mampu membantu korban bullying untuk mengurangi kecemasan, oleh karena itu pada penelitian ini akan diuji efektivitas menulis ekspresi terhadap kecemasan anak korban bullying.

\section{METODE}

Penelitian ini merupakan penelitian eksperimen dengan menggunakan Pretest Posttest Control Group Design yang melakukan pengukuran sebelum dan setelah diberi perlauan pada kelompok kontrol dan eksperimen (Latipun, 2008). Responden penelitian merupakan anakanak korban bullying dengan karakterik memiliki rentang usia 9-12 tahun, memiliki skor IQ berada pada kategori normal dan memiliki skor kecemasan dengan kategori sedang ( $(38 \leq \mathrm{X}<$ 76) dan kategori tinggi $(X \geq 76)$. Responden diperoleh dengan terlebih dahulu melewati tahap screening menggunakan kuisoner bullying yang mengadaptasi dan memodifikasi The Revised Olweus Bully/Victim Questionnaire dari Dan Olweus pada tahun 1996 untuk mengetahui 
keterlibatan sebagai korban bullying.

Responden yang memiliki kriteria sebagai korban, akan mengisi Spence Children's Anxiety Scale (SCAS) untuk mengetahui tingkat kecemasan korban. Skala SCAS merupakan skala liket dengan 5 pilihan jawaban. Skala ini terdiri dari 29 aitem yang mencerminkan simtom kecemasan dari enam area kecemasan dengan nilai reliabiltas $\left(\mathrm{r}_{\mathrm{ix}}=0.89\right)$. Responden yang memenuhi kriteria akan diberi tes Colour Progressive Matrix (CPM) untuk mengetahui golongan intelektual responden. Dari 75 orang siswa yang mengikuti proses screening, diperoleh sebannyak 8 orang siswa (2 laki-laki dan 6 perempuan) yang memenuhi kriteria sebagai responden penelitian yang kemudian dibagi menjadi kelompok kontrol sebanyak 4 orang dan kelompok eksperimen masing-masing sebanyak 4 orang.

Proses pelaksanaan terapi berlangsung sebanyakk 6 sesi. Sesi pertama merupakan pembukaan, petemuan kedua hingga kelima merupakan proses terapi dan pertemuan keenam merupakan penutup. Selama proses terapi, responden diberi lembar tugas, sebagai data penunjang dalam penelitian ini. Hasil pengamatan tingkat kecemasan sebelum dan sesudah diberi terapi akan dianalisis menggunakan uji beda Mann Whitney dan Wilcoxon.

\section{HASIL}

Tabel 1

Statistik deskriptif kelompok eksperimen dan kelompok kontrol

\begin{tabular}{clccccc}
\hline Kondisi pengukuran & Kelompok & N & Mean & SD & Max & Min \\
\hline \multirow{2}{*}{ Pretest } & Eksperimen & 4 & 66,00 & 19.131 & 94 & 51 \\
& Kontrol & 4 & 45.75 & 9.394 & 57 & 38 \\
\hline \multirow{2}{*}{ Posttest } & Eksperimen & 4 & 66,50 & 20.761 & 97 & 52 \\
& Kontrol & 4 & 60.75 & 24.061 & 93 & 40 \\
\hline
\end{tabular}

Tabel 1. menunjukkan perbedaan pretest dan postest penelitian pada kelompok eksperimen dan control. Sedang melalui tabel 2 diketahui bahwa tidak ada perbedaan tingkat kecemasan pada kelompok eksperimen dengan kelompok kontrol setalah terapi menulis ekspresif diberikan $(\mathrm{p}>0.05)$ dan $\mathrm{r}=-0.72$.

Tabel 2

Hasil uji komporatif skor kecemasan kelompok eksperimen dan kelompok kontrol

\begin{tabular}{ccccc}
\hline Uji statistik & Kelompok & Kondisi pengukuran & Effect size $(\mathbf{r})$ & P \\
\hline \multirow{2}{*}{ Mann Whitney } & & pretest & -0.20 & $0.042^{*}$ \\
& & posttest & -0.72 & 0.564 \\
\hline \multirow{2}{*}{ Wilcoxon } & Eksperimen & & -0.13 & 0.715 \\
& Kontrol & & -0.65 & 0.068 \\
\hline \multirow{2}{*}{ Keterangan $: *$ p $<0,05$} & & &
\end{tabular}

Selain itu dari hasil uji Wilcoxon pada kelompok eksperimen juga terlihat tidak ada perbedaan tingkat kecemasan antara sebelum dan sesudah diberikan terapi menulis ekspresif (P $>0.05)$ dan $r=-0.13$. Dapat disimpulkan, terapi menulis ekspresif tidak efektif menurunkan kecemasan anak korban bullying. Untuk perbandingan skor kecemasan setiap responde dengan skor rata-rata kelompok dapat dilihat pada grafik berikut: 


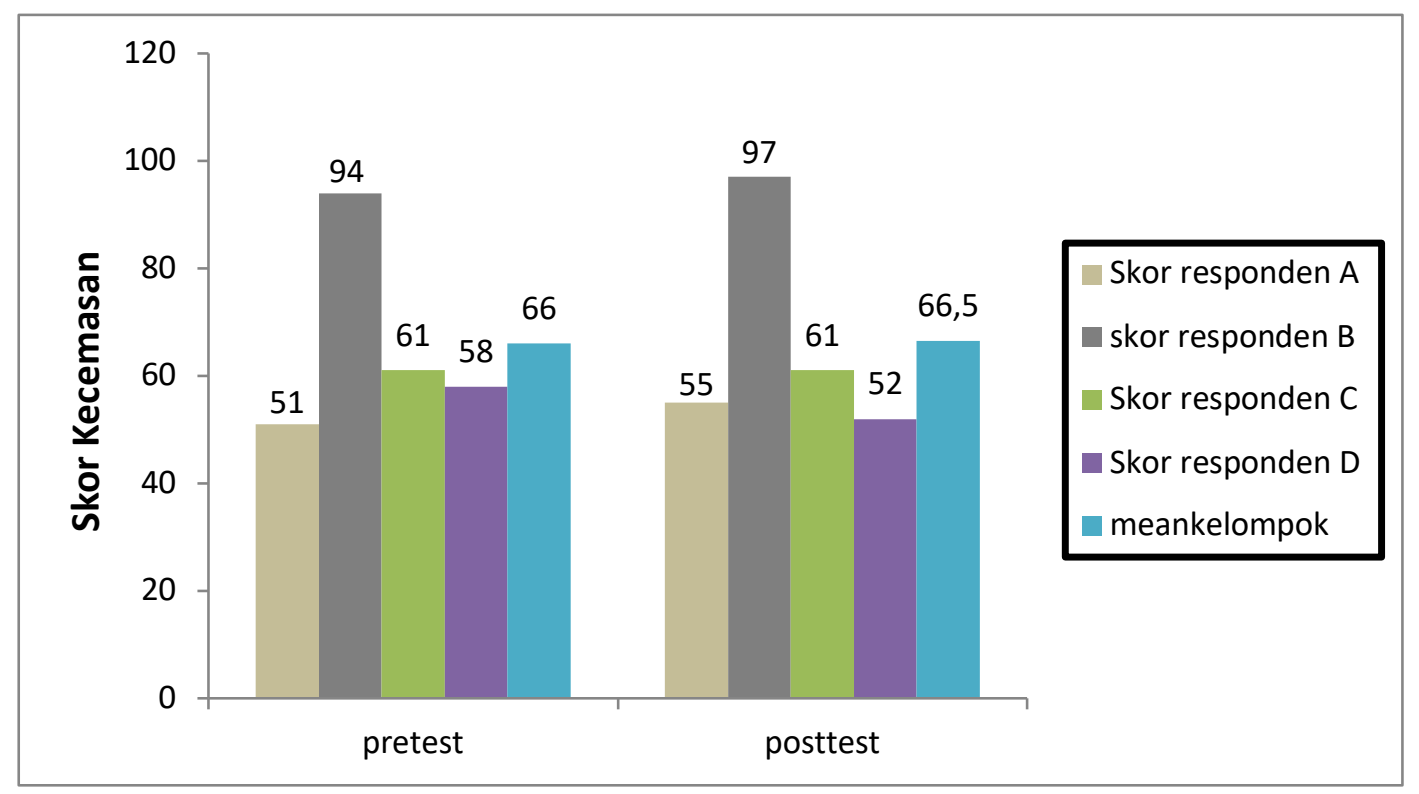

Gambar 1.1: Perbandingan skor kecemasan responden

Hasil grafik di atas memperlihatkan bahwa pada kondisi sebelum terapi sebanyak 3 orang responden memiliki skor kecemasan di bawah rerata skor kecemasan kelompok, yaitu responden $\mathrm{A}, \mathrm{C}$ dan $\mathrm{D}$ sedangkan skor kecemasan responden $\mathrm{A}$ di atas rata-rata skor kecemasan kelompok. Pengukuran pada kondisi setelah dilakukan terapi, Skor kecemasan responden A, C dan D di bawah rerata skor kecemasan kelompok, sedangkan skor responden B, berada di atas rerata skor kelompok. Bila memperhatikan skor kecemasan pada kondisi posttest dan pretest, terlihat bahwa terdapat 1 orang responden yang menunjukkan penurunan skor kecemasan yaitu responden D. Hal ini berarti terapi menulis ekspresif mampu menurunkan kecemasan pada responden $\mathrm{D}$.

\section{DISKUSI}

Berdasar pada uji Mann Withney berarti tidak ada perbedaan tingkat kecemasan pada responden eksperimen dengan responden kontrol. Hal ini memperlihatkan bahwa terapi menulis ekspresif tidak efektif menurunkan kecemasan anak korban bullying. Untuk mengetahui efektivitas terapi menulis ekspresif pada kelompok eksperimen itu sendiri, maka dilakukan uji Wilcoxon. Hasil uji wilcoxon diperoleh juga memperlihatkan hasil tidak ada perbedaan kecemasan antara sebelum dan sesudah dilakukan terapi menulis ekspresif. Hasil pemberian terapi menulis ekspresif yang tidak efektif terjadi pula pada penelitian lainnya, seperti hasil penelitian Murti dan Hamidah tahun 2012. Penelitian tersebut bertujuan untuk menguji efektivitas terapi menulis ekspresif terhadap depresi. Dari hasil penelitian diketahui bahwa tidak ada perbedaan depresi kelompok eksperimen dengan kelompok kontrol (Murti dan Hamidah, 2012). Dengan demikian, berdarkan hasil penelitian tersebut, maka terapi menulis ekspresif tidak efektif untuk mengatasi permasalahan psikologi.

Beberapa data selama proses terapi menulis yang didapat dan diperkuat oleh beberapa teori yang ada, maka temuan tersebut dapat menjelaskan terapi menulis ekspresif tidak efektif menurunkan kecemasan pada responden, diantaranya, pertama proses pencapaian insight pada responden tidak berlangsung lancar. Poses pencapaian insigt terapi menulis berlangsung pada tahap juxtaposition. Tahap ini merupakan tahapan, dimana responden memperoleh kondisi 53

Salmiyanti-Kecemasan anak korban bullying 
baru, serta menginspirasi perilaku, sikap dan pemahan lebih tentang dirinya. Saat responden telah mendapat insight, akan dimotivasi untuk dapat mengaplikasi hal tersebut dalam kehidupan sehari-hari (Malchiodi, 2007). Pada tahapan ini, responden dibantu memperoleh pikiran positif dengan cara mengajukan beberapa pertanyaan tentang kelemahan dan kelebihan dirinya. Selanjutnya responden diajak untuk melakukan self talk yaitu mengatakan kepada diri sendiri pikiran-pikran positif yang diperoleh.

Dari hasil pelaksanaan, responden kesulitan untuk mengetahui kelemahan yang dimiliki yang menyebabkan mereka mendapat bullying yang memunculkan kecemasahan. Begitupula untuk kelebihan yang dimiliki berupa tindakan yang dapat dilakukan dan kemudian diaplikasikan dalam kehidupan untuk mengurangi rasa cemas tersebut. Proses ini kurang mampu memfasilitasi tujuan dari tahap juxtapotision dari terapi menulis ekspresif. Oleh karenanya proses terapi yang dilaksanakan kurang mampu membantu responden untuk mencapai insight yang diharapkan, sehingga mampu mengurangi kecemasan yang dirasa.

Kedua, karakteristik menulis ekspresif tidak terpenuhi salah satu karakterstik menulis ekspresif adalah self expression. Individu dapat mengungkapan perasaan serta persepsi tentang suatu peristiwa dengan bebas, sehingga mendapat pemahaman diri, emosi, pemecahan masalah dan perasaan well-being yang lebih baik (Malchiodi, 2007). Sedangkan pada proses terapi, subjek belum cukup ekspresif mengungkapkan dan mengeksplor pikiran dan perasaan saat mengalami bullying, namun responden lebih mendeskripsikan kejadian bullying yang dialami. Dari tulisan yang ditulis tersebut, belum terlihat adanya proses kognitif seperti refleksi diri (memahami, menyadari dan mengetahui), sehingga muncullah pemahaman diri dan pemecahan masalah yang lebih baik. Hal ini dikarenakan dalam proses kognitif ada proses analisa serta pembalajaran mengenai hal baru dari pengalaman-pengalaman yang dialami (Plupth,, 2012).

Ketiga, responden masih mengalami bullying. Lingkungan dapat menjadi penyebab munculnya kecemasan pada individu, yaitu ketika lingkungan tidak lagi dirasa aman melainkan memberikan pengelaman tidak menyenangkan (Ramaiah, 2003) dan salah satu pengalaman yang tidak menyenangkan tersebut adalah bullying. Bullying sebagai pengalaman tidak menyenangkan terjadi di sekolah menyebabkan muncul kecemasan pada anak (Ong, 2003) dan semakin tinggi pengalaman tersebut akan berhubungan dengan meningkatnya gejelasa kecemasan (Porsteinsdottir, 2014). Berdasarkan kuisoner bullying yang diisi oleh responden, diketahui frekuensi bullying yang dialami responden A lebih sering dibanding responden lainnya yaitu terjadi setiap hari dan 3 responden lainnya hanya 2 atau 3 kali seminggu. Pada saat terapi berlangsungpun responden A dan B, masih mengalami bullying. Dari hasil skor kecemasan responden sebelum dan setelah dilakukannya terapi juga terlihat adanya peningkatan skor kecemasan. Berdasarkan kondisi tersebut, maka dapat dikatakan bahwa tingginya intensitas bullying serta masih mengalami bullying selama terapi berlangsung, dapat menjadi salah satu faktor yang menyebabkan skor kecemasan subjek tidak mnurun.

Keempat, jarak dan durasi menulis. Jarak dan durasi menulis yang dilakukan pada saat terapi menjadi salah satu faktor yang mempengaruhi efektivitas terapi menulis ekspresif (Soper \& Bargen, 2001). Hal ini juga terlihat dari hasil penelitian Smyth's pada tahun 1998 bahwa jarak pelakasanaan menulis berpengaruh kuat terhadap efektivitas menulis ekspresif, namun berbeda dengan durasi menulis, yang tidak terdapat pengaruh yang kuat terhadap efektivitas menulis ekspresif, dimana berdasarkkan hasil penelitian bahwa menulis sekali seminggu selama satu bulan lebih efektif dibandingkan menulis 4 kali selama seminggu (Soper \& Bargen, 2001). Pada penelitian ini, terapi dilaksanakan sebanyak 4 kali yang dilaksanakan setiap hari dengan lamanya waktu mengerjakan selama 30 hari. Hal ini berarti pelaksanaan terapi menulis ekspresif yang dilakuka setiap hari, belum mampu menjadikan terapi menulis ekspresif efektif untuk menurunkan kecemasan. 
Kelima, perbedaan dan karakteristik individu. Mengungkapkkan peristiwa dan perasaan yang tidak menyenangkan melalui kegiatan menulis terlihat relevan terhadap usia, jenis kelamin, etnik, kelas sosial dan tingkat pendidikan, akan tetapi adanya perbedaan dan karakteristik individu yang dapat mempengaruhi efektivitas menulis ekspresif (Soper \& Bergen, 2001). Salah satunya perbedaan karakter antara perempuan dan laki-laki. Pada anak perempuan, mereka lebih mampu mengekplor pikiran dan perasaannya, sehingga akan lebih banyak informasi, detail, emosioal dan lebih banyak meceritakan situasi interpersonal mengenai pengalamannya dibandingkan laki-laki (Fivush,Reynold,Marin \& Crowford. 2007). Hal ini juga ditemukan pada hasil penelitian, dimana responden perempuan lebih banyak menuliskan informasi, detail, emosional dibandingkan responden laki-laki dan hasil skor kecemasan pada respon laki-laki yaitu responden A menunjukkan adanya peningkatan skor kecemasan dibanding subjek perempuan.

Meskipun dari hasil uji statistik didapat hasil terapi menulis ekspresif tidak efektif menurunkan kecemasan, namun berdasarkan skor kecemasan pada setiap responden terlihat adanya penurunan skor kecemasan pada respon D. Penurunan skor kecemasan tersebut, dikarenakan adanya proses katarsis emosi yang berlangsung pada responden saat mengeksplor pikiran dan perasaannya. selain itu, responden memperoleh pemahaman baru tentang kelebihan dan kelemahan dirinya sehingga memberikan rasa percaya diri dan keberanian jika mengalami bullying dan mengatasi kecemasannya. Responden mengungkapkan sebelumnya ia belum pernah mengungkapkan pengalaman bullying yang dialami, karena sebagain dari orang-orang terdekat tidak memberikan dukungan tetapi balik memarahi. Pada saat proses terapi, responden mampu mengungkapkan perasaan marah, kesal dan benci, sehingga merasa lebih baik, senang serta perasaan negatif yang sebelumnya dirasakan sedikit berkurang. Keadaan ini sebagaimana disebutkan oleh Fivush et .al (2007) bahwa saat individu mampu mengungkapkan dan melepaskan perasaan dan pikirannya tentang kesulitan dan hambatan yang dialami, maka keadaan tersebut memberikan katarsis individu. Dengan demikian pengalaman yang dialami oleh responden selama terapi menulis ekspresif, memperlihatkan bahwa terapi menulis ekspresif memberikan efek positif bagi responden D dan menurunkan kecemasan yang dialaminya.

\section{KESIMPULAN}

Dari hasil penelitian yang dilakukan dapat disimpulkan bahwa terapi menulis ekspresif tidak efektif untuk menurunkan kecemasan pada anak korban bullying. Terdapat beberapa faktor yang mempengaruhi terapi menulis menjadi tidak efektif, yaitu proses pencapaian insight pada responden tidak berlangsung lancar, karakteristik menulis ekspresif tidak terpenuhi salah satu karakterstik menulis ekspresif adalah self expression, responden masih mengalami bullying, jarak dan durasi menulis dan perbedaan dan karakteristik individu. Temuan lain yang diperoleh dari penelitian ini yaitu, terapi menulis memberikan efek positif ketika digunakan sebagai media katarsis. Untuk memperoleh hasil yang lebih baik pada penelitian berikutnya, maka beberapa hal yang perlu diperhartikan yaitu pertimbangan rentang waktu pelaksanaan menulis ekspresif, kemungkinan masih adaanya responden yang mengalami bullying selama proses terapi serta menambahkan kegiatan pada tahap juxtaposition.

\section{DAFTAR PUSTAKA}

Bolton, Gillie. (1999). The Therapeutic Potential of Creatie Writing, Writing My Self. London and Philadelphia: Jessica Kingsley Publisher. 
Bolton, Gillie. (2011). Write Yourself, Creatie Writing and Personal Development. London and Philadelphia: Jessica Kingsley Publisher.

Dadds, M. R., \& Barrett, P. M. (2001). Practitioner review: Psychological management of anxiety disorders in childhood. Journal of Child Psychology and Psychiatry and Allied Disciplines, 42(8), 999-1011. https://doi.org/10.1111/1469-7610.00798

Firmansyah, T. (2014). Aduan Bullying Tertinggi. Republika Online. Diakses pada tanggal 19 Februari 2015 dari http://www.republika.co.id

Fivush, Robin., Martina, Reynold., Crowford, Megan \& Marin, Kelly. (2007). Children's Narrative And Well-Being. Journal of cogition and emotion. 21 (7). 1414 - 1434 DOI: $10.1080 / 02699930601109531$

Gillette \& Danniels. (2009). Bullying At School And Online. Education.com Holdings, Inc Hauggard, Jeffrey J. (2008). Child Psychopatology. McGrawHill: New York Latipun. (2008). Psikologi Eksperimen. Malang: UMM Press

Malchiodi, C.A. (2007). Expressive Therapies. New York: The Guilfor Press

Murphy, M.M \& Banas, S.L. (2009). Dealing with Bullying. New York: An Imprint of Infobase Publising

Murti, Reyza Dahlia \& Hamidah. (2012). Pengaruh Expressive Writing terhadap Depresi pada Remaja SMK di Surabaya. Jurnal Psikologi Klinis dan Kesehatan Mental. Vo.1 No.02. 87-93 diakses pada tanggal 5 Mei 2020 dari http://journal.unair.ac.id

Ong, F. (2003). Bullying at School. California: CDE Press

Pennabaker, J.W \& Chung, C.K. (2007). Expressive writing and links to mental and physical health.In H.S. Friedman (Ed), Oxford handbook of health psychology. New York, NY: Oxford University Press

Plupth, Kate M. (2012). Alexitymia, Emotional Intelligence And Their Relation to Word Usage in Expressive Writing. Scripps Senior Theses diakses pada tanggal 5 Mei 2020 dari https://pdfs.semanticscholar.org

Porsteinsdottir, Elisa. (2014). Effect of Bullying on Symptoms Depression and Anxiety, The Importance of Parental Support. Department of Psychology School of Busines, diakses pada tanggal 5 Mei 2020 dari https://pdfs.semanticscholar.org

Savitri Ramaiah. (2003). Kecemasan Bagaimana Mengatasi Penyebabnya.Jakarta: Pustaka Populer Obor.

Soper Barlow \& Bergen, C.W.Von. (2001). Employment Counseling And Life Stressors; Coping Through Expressive Writing. Journal of employment counseling. Vol 8. 150-160. Diakses pada tanggal 5 Mei 2020 dari http://homepages.se.edu

Supriyantini, Sri. (2010). Perbedaan Kecemasan dalam Menghadapi Ujian Antara Siswa Program Reguler dengan Siswa Program Akselarasi. Universitas Sumatera Utara. Diakses pada tanggal 5 Mei 2020 dari http://repository.usu.ac.id

Swearer, S.M., Espelage, D.L \& Napolatino, S.A. (2009). Bullying Prevention Realistic Strategies for School. Canada: Guilford Publication, Inc 